\title{
Lancashire Dialect Examination in Elizabeth Gaskell's Mary Barton
}

\author{
Amina AZZOUZ \\ Department of English, Faculty of Letters and Languages \\ University of Tlemcen - Algeria \\ Wassila HAMZA REGUIG-MOURO \\ Department of English, Faculty of Letters and Languages \\ University of Tlemcen - Algeria
}

\begin{abstract}
Dialect and sociolinguistics have a mutual relationship considering language, with its varieties, a tool of characterization; one's speech expresses one's age, cultural and educational level, gender, social class, ethnic group, etc. Literature is the artistic field that holds all existing language diversities. Hence, some authors (like Dickens and Gaskell, and many others) embrace dialect employment in standard literary works stressing on its aesthetic function. The concern in this paper is on the novel Gaskell Mary Barton (1848), where Lancashire's dialect is generously used. So, what does literary dialect means? What is the scope of Lancashire, and what are its features? How did Gaskell employ it? This paper aims at highlighting the phenomenon of literary dialect and how authors use it to achieve authenticity.
\end{abstract}

Keywords: Characterization, dialect, Elizabeth Gaskell, literary dialect, literature, Mary Barton

Cite as: AZZOUZ, A., \& HAMZA REGUIG-MOURO,W. (2020). Lancashire Dialect Examination in Elizabeth Gaskell's Mary Barton. Arab World English Journal for Translation \& Literary Studies 4 (2) 240-246 . DOI: http://dx.doi.org/10.24093/awejtls/vol4no2.18 


\section{Introduction}

Literature is the human artistic interpretation of life in the form of written texts where all the valuable aesthetic devices enlist to produce precious literary works that stem from reality. Mainly, literary dialect may be a subtle way to illustrate this concept as authors codify the different dialects that are the informal forms of language in the formal written texts to portray real life. The literary dialect has always been a subject of dispute between dialogists and dialect writers and linguists. The sociolinguistic factor of literary dialect was the primary motivation of the writers to use it as it serves as an identity marker that facilitates shaping the character's personality in the readers' minds.

Elizabeth Gaskell (1810-1865) is one of the dialect writers who employed dialect in many of her writings, fundamentally, Mary Barton, where she codified the Lancashire dialect to epitomize her characters well and make them authentic.

\section{Literary Dialect Concept}

Dialect is a sub-branch of language considered as informal, "which is associated with a particular area/and or/ with a particular social class or status group" (Trudgill, 2003, p. 23). The employment of this linguistic feature in literature has always been questioned, whether it is or not suitable to include informal language form in a formal literary text. Yet, dialect writers defend this issue by stressing the usefulness of literary dialect and how it is sociolinguistically related to the identification of the characters' age, nationality, level of education, etc. Milton (2002) defines it as a "stylistic construct. It is a marked code that invites readers to go beyond denotative meanings to seek the specific connotations of the speech depicted" (p. 5).

Zanger (1966) gives a simple definition of literary dialect as being "the attempt to indicate on the printed page, through spellings and mis-spellings, elisions, apostrophes, syntactical shifts, signals, etc., the speech of an ethnic, regional or social group" (p. 40). The goals of dialect use in standard literary works not only lie in characterization but also to attract a broader category of readers by giving them the ability to test new flavours of language as Shorroks (1996) explains:

The representation of non-standard speech in literature that is otherwise written in Standard English ... and aimed at a general readership; dialect literature, on the other hand, is defined as aimed essentially, though not exclusively, at non-standard-dialect-speaking readers ( $\mathrm{p}$. 28)

According to scholars, literary dialect has to be treated not only as a literary issue but also as a scientific theory and "should be guided by the principles of descriptive linguistics and should be controlled by the findings of linguistic geography" (Ives, 1950, p. 173). Dialect may be divided into two kinds; the regional and the social, and then, literary dialect may either be a marker of region or society. The local is that variety of language spoken within specific geographical borders and one can "perceive phonological distance indirectly" (Heeringa \& Nerbonne, 2001, p. 398) as there are "sharp borders between dialect areas" (Heeringa \& Nerbonne, 2001, p. 399). This kind of dialect is employed by writers in their literary works to make the characters' geographical

Arab World English Journal for Translation \& Literary Studies 
background familiar to the reader. As for the social dialect, also called the sociolect, it is related to the social parameters including, age, level of education, gender, social class, etc. Behravan (2012) mentions that "social factor shows that members of a specific socioeconomic class such as working-class dialects might have different dialects compared to high-class businessmen" (p. 16).

The appearance of realism as a movement in response to romanticism enriched the writers' motivation for literary dialect as it, as its name indicates, focuses on the portrayal of the intrinsic life, the different social classes' problems, and the real mood of society. Language then, with its varieties involving dialect, builds a bridge between the reader and reality as it depicts the characters' portraits. Kramsch (1998), in this respect, notes that "words also reflect their authors' attitudes and beliefs, their point of view, that are also those of others, in both cases, language expresses cultural reality... language embodies cultural reality ... language symbolizes cultural reality" (p. 3)

Keeping the focus on the relationship between language and the social attitude of the person and how the social status (age, cultural level, gender, social class) affects one's linguistic character; an educated person will not use the same language features of an ignorant. Walpole (1974) believes that:

If the character is from an inferior social class, if he is of an ethnic minority, if he is foreign, rustic, or ill-educated, or if he is from a few choice locations [...] his dialogue becomes branded as substandard by the use of colloquialisms, solecisms, and eye dialect (p. 193)

The accuracy which literary dialect provides breaks the barriers between the writers and his audience as it makes them feel closer to the stories' dialect characters. The literary dialect notion was, after that, acknowledged as a sociolinguistic branch as speech diversity forms are automatically linked to social factors.

\section{Lancashire Dialect}

The Lancashire dialect refers to the vernacular within the scope of the Lancashire county situated in the northwest of England. It is bounded to the North by today's Cumbria, to the south by Merseyside and the west by Yorkshire county. The county arose during the industrial revolution, by the $1830 \mathrm{~s}$, and became a central trade field where "approximately $85 \%$ of all cotton manufactured worldwide was processed in Lancashire" (Gibb, 2005, p. 13).

Arab World English Journal for Translation \& Literary Studies 


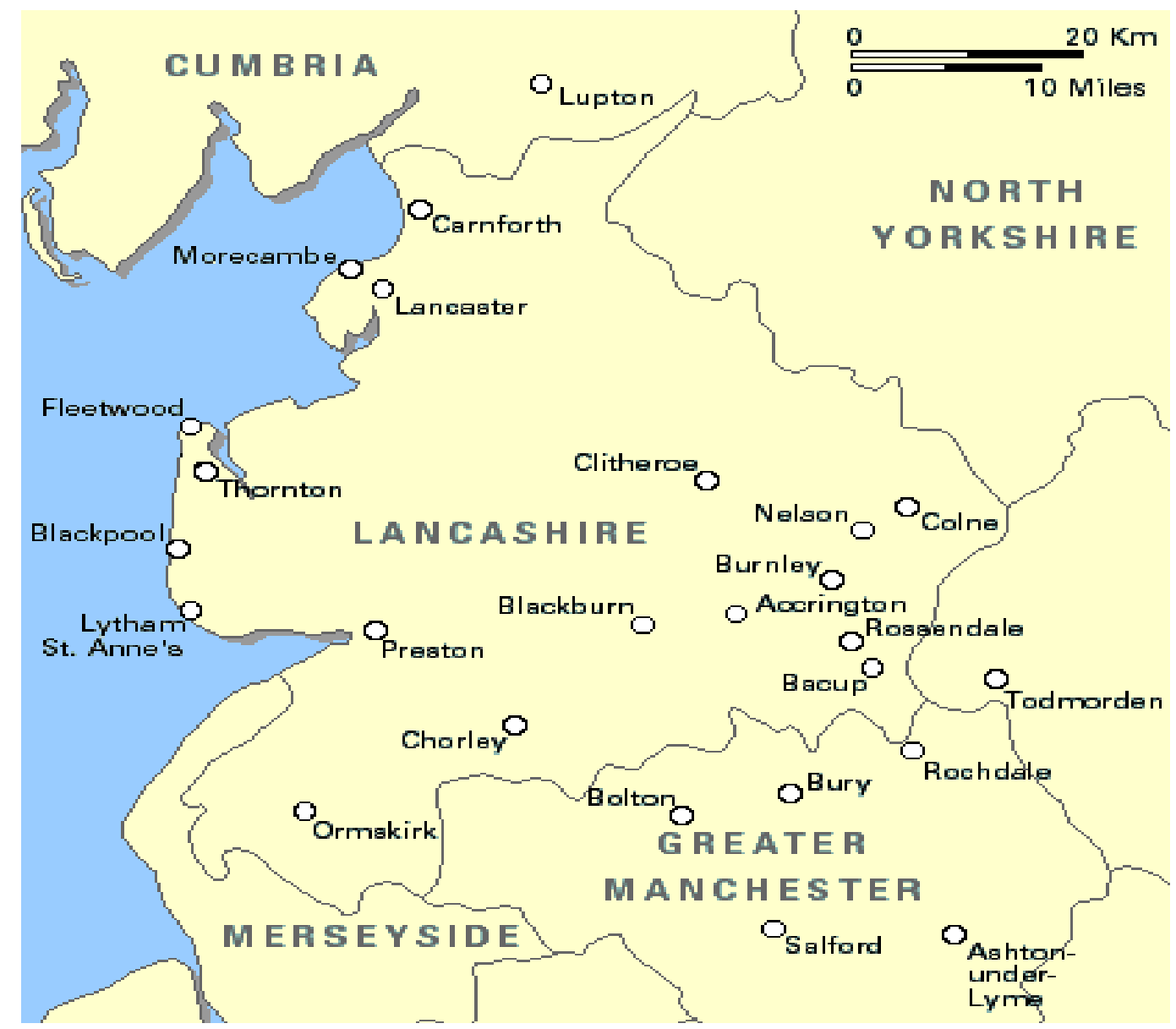

Figure 1. Geographical Borders of Lancashire County

Source: https://www.4hotels.co.uk/uk/england-lancashire.html

Lancashire dialect has several grammatical, phonological and lexical features, some of them are the followings:

1 - The non-moderate use of the past form of to be: was and were may be used with all pronouns

Example: Dialects was various / Dialect were various

2 - The suffix ' $s$ ' was added to verbs with the third person singular in the present tense may be added to other pronouns

Example: Grammatical rules need to be well understood

3 - The definite pronouns gloating /the/ becomes /t/

4 - Words like 'light', 'night', 'right', may sound 'leet', 'neet', 'reet' /li:t, ni:t, ri:t/ (Trudgill, 1999, p. 22)

5 - /t/ may turn to /d/: 'cannot' becomes 'connod'

6 - /a/ is replaced by /o/: 'many' and 'can' turn to 'mony' and 'con'

7 - The word 'much' turns to 'mich' 
8 - Words like 'about', 'without', 'mouth' turn to 'abeawt', 'beawt', 'meawth'

9 - Letter doubling: 'above', 'coat' become 'aboon', 'coaat'

In literature, Lancashire dialect was pervasive among writers during the 19th century; its employment in the printed literary works reached its climax "Martha Vicinus was the first historian to make serious use of Lancashire dialect literature” (Salveson, 1993, p. 2)

Salveson (1993) believes "dialect literature in Lancashire went through a number of distinct phases" (p. 5). The first one starts from the emergence of the flourishment of dialect literature in the mid-eighteenth to the mid-nineteenth century, where "typical products comprise a combination of broadsheet songs, satirical verse, and humorous occasional pieces" (Salveson, 1993, p. 5). The pioneer of this figure is John Collier ('Tim Bobbin'). The second phase "begins in the early 1850s and lasts until the end of the century. It is represented in the work of Edwin Waugh, Ben Brierley, J.T. Staton, and slightly later Samuel Laycock" (Salveson, 1993, p. 5). The third period witnessed the appearance of a new generation of Lancashire dialect writers, mainly Allen Clarke. The last one starts from the end of the first World War to the death of Allen Clarke (Salveson, 1993, p. 5).

\section{Lancashire Dialect in Mary Barton}

Elizabeth Gaskell $(1810$ - 1865) was an outstanding woman writer who strongly marked her name in the field of feminism and literature, benefiting from her settlement in Manchester to produce notable literary works dealing with the working-class preoccupations in the industrial Manchester. Cecil described her as "a typical Victorian woman" (198). This interest in the low class was not welcome, since dealing with this issue was seen as a male matter rather than a female topic. It was believed that she might "know too little about the cotton industry", and so she has no "right to add to the confusion by writing about it" (Chapman, 1999, p. 28).

Mary Barton is Elizabeth Gaskell's first novel published in 1848. The story is set in the Green Hey Fields in Manchester during the 1840s. It deals with the status of the working class during the industrial revolution:

Mary Barton dramatizes the urban ills of the late 1840s, an era marked by industrial conflict, by strikes and lock-outs, by low wages and enforced unemployment, by growing class consciousness and by Chartist agitation which reached its climax in the year of the novel's publication (Sanders, 1929, p. 417).

Though Gaskell was not a dialect speaker, she employed it in this novel to achieve authenticity and well-characterize her characters. In this passage, she makes use of a widely prominent Lancashire word "nesh" in the mouth of a dialect character John Barton which means soft or tender whose etymology goes back to old English; "Sit you down here: the grass is well nigh dry by this time; and you're neither of you nesh folk about taking cold" (Gaskell, 1848, p. 2).

Table1 will present a set of Lancashire words Gaskell used in Mary Barton with their explanation:

Arab World English Journal for Translation \& Literary Studies 
AWEJ for Translation \& Literary Studies Volume, 4 Number 2 May 2020

Table 1: Lancashire words used by Gaskell in Mary Barton (1848)

\begin{tabular}{|c|c|c|}
\hline Lancashire Word & Standard Word & Example of use from the novel \\
\hline Childer & Children & $\begin{array}{l}\text { "Cannot bring mysel to let my two } \\
\text { childer go in one day" (p. 42) }\end{array}$ \\
\hline Clooas & Clothes & $\begin{array}{l}\text { "Oi'm a poor cotton-weyver, as mony a } \\
\text { one knoowas, Oi've nowt for t' yeat, an' } \\
\text { oi've worn eawt my clooas ..." (p. 18) }\end{array}$ \\
\hline Heawse & House & $\begin{array}{l}\text { "When they seed as aw t' goods were } \\
\text { ta'eneawt o' } t \text { ' heawse; } \\
\text { Says one chap to th' tother ..." (p. 18) }\end{array}$ \\
\hline Mun & Must & $\begin{array}{l}\text { "It is, Mary! and yet what can I do? Folk } \\
\text { mun live; and I think I should go blind } \\
\text { any way, and I daren't tell } \\
\text { grandfather..." (p. 26) }\end{array}$ \\
\hline Neaw & now & $\begin{array}{l}\text { "We shifted, an' shifted, till neaw we're } \\
\text { quoite fast" (p. 18) }\end{array}$ \\
\hline $\mathrm{O}^{\prime}$ & Of, on & $\begin{array}{l}\text { " I've been to both doctors again and } \\
\text { now they're both } \mathrm{o}^{\prime} \text { the same story" (p. } \\
\text { 25) }\end{array}$ \\
\hline Owd & Old & $\begin{array}{l}\text { "We'd neawt left bo' th' owd too' " (p. } \\
\text { 18) }\end{array}$ \\
\hline Sin' & Since & $\begin{array}{l}\text { "if they can't give us what we're all } \\
\text { crying for sin' the day we were born." } \\
\text { (p. 48) }\end{array}$ \\
\hline Sowd & Sold & $\begin{array}{l}\text { "But he wur too lat, fur owd Billy o' th' } \\
\text { Bent, Had sowd th' tit an' cart, an' ta'en } \\
\text { goods for th' rent" (p. 18) }\end{array}$ \\
\hline They'n & They have & $\begin{array}{l}\text { "You'll say (at least many a one does), } \\
\text { they'n* getten capital an' we'n getten } \\
\text { none" (p. 35) }\end{array}$ \\
\hline
\end{tabular}

\section{Conclusion}

An ultimate relationship between literary dialect and sociolinguistics exists. Authors, through dialect employment, seek realism, authenticity, and characterization. Gaskell, through Lancashire dialect use, did so and became one of the prominent writers thanks to her clever use of vernaculars. Therefore, Mary Barton gains over an impressive success.

Though dialect authors have suffered from neglect and underestimation, they succeeded in proving, through their works, that vernacular is not an inferior variety of language but a type of speech that refers to the person's social behaviour; the fact that reinforced its usage by a substantial rate of authors.

Arab World English Journal for Translation \& Literary Studies 
AWEJ for Translation \& Literary Studies Volume, 4 Number 2 May 2020

About the Authors

Amina AZZOUZ is a doctoral student at Aboubekr Belkaid University of Tlemcen, undertaking research in Language and Literature Studies. ORCid ID: https://orcid.org/0000-0002-3969-4818

Wassila HAMZA REGUIG MOURO is an Associate Professor at the Department of English, University of Tlemcen. She holds a PhD in Literature and civilization as well as a Habilitation. Her research interests are mostly literary and turn around Postmodernism (metafiction, intertextuality, dialogism and narration...), Women's writing, Postcolonial literature and the Victorian era. ORCid ID: https://orcid.org/0000-0002-5011-3551

\section{References}

Azevedo, M., M. (2002). "Considerations on Literary Dialect in Spanish and Portuguese. Hispania. 85 (3). Pp. 505-514. American Association of Teachers of Spanish and Portuguese

Behravan, H. (2012). Dialect and Accent Recognition. The University of Eastern Finland.

Cecil, D. (1934). Early Victorian Novelists. London: Constable and Company Limited.

Chapman, A. (1999). Elizabeth Gaskell: Mary Barton-North and South. Palgrave Macmillan.

Gaskell, E. (1848). Mary Barton. Two Vols. London: Chapman and Hall.

Gibb, R (2005). Greater Manchester: A Panorama of People and Places in Manchester and its Surrounding Towns. Myriad.

Heeringa, W. and Nerbonne J. (2001). Language Variation and Change. Cambridge University Press

Ives, S. (1950). "A Theory of Literary Dialect". Tulane Studies in English 2: 137.

Kramsch, C. (1998). Language and Culture. Oxford: Oxford University Press.

Salveson P. S. (1993). Literary Use of Dialect: Case of Walker's The Color Purple. 6 (1), 2018. pp 2-5

Sanders, Gerald De Witt. (1929). Elizabeth Gaskell; With a Bibliography by Clark S. Northup. New Haven: Yale University Press.

Shorrocks, G. (1996). "Non-Standard Dialect Literature and Popular Culture". In Speech Past and Present: Studies in English Dialectology in Memory of OssiIhalainen, J. Klemola, M. Kyto and M. Rissanen (eds), 385-411. Frankfurt am Main: Peter Lang

Trudgill, P. (2003). A Glossary of Sociolinguistics. Oxford University Press

Trudgill, P. (1999). The Dialects of England. Edition 2. Oxford: Wiley \& Blackwell

Walpole , J . (1974). College Composition and Communication. 25 (2). Pp. 193

Zanger, J. (1966). Literary Dialect and Social Change, Midcontinent American Studies Journal, 7 (2). Pp.40-48.

Arab World English Journal for Translation \& Literary Studies 